\title{
Pandemia e biopolítica: uma leitura foucaultiana sobre as intervenções de Agamben e Esposito
}

\author{
Pandemic and biopolitics: a Foucaultian reading \\ of the interventions of Agamben and Esposito
}

Fábio Gonzaga Gesueli ${ }^{1}$

Eduardo Arruda Passos²

\footnotetext{
1 Mestre em Ciências da Religião e Graduado em Ciências Sociais pela Pontifícia Universidade Católica de Campinas. É membro do grupo de pesquisa "Ética, política e religião: questões de fundamentação".

E-mail: fabiogesueli@gmail.com Orcid: http://orcid.org/0000-0003-1287-6811 Lattes: http://lattes.cnpq.br/7217677676665542
}
2 Mestre em Ciência Política e Relações Internacional pela Universidade Nova de Lisboa. Graduando em filosofia na PUC-Campinas. É membro do grupo de pesquisa Ética, política e religião: questões de fundamentação, da Pontifícia Universidade Católica de Campinas.
E-mail: e_arrudapassos@hotmail.com Orcid: http://orcid.org/0000-0002-6000-8165 Lattes: http://lattes.cnpq.br/0925422472942402

Resumo: Os filósofos Giorgio Agamben e Roberto Esposito mobilizaram as suas concepções de biopolítica para opinarem sobre a pandemia do vírus SARS-CoV-2. O objetivo deste artigo é fazer uma leitura foucaultiana sobre esses posicionamentos. Nossa proposta se fundamenta em três momentos: uma análise do conceito de biopolítica a partir dos cursos de Foucault no Collège de France; em seguida fazemos uma análise das intervenções de Agamben e de Esposito à luz de suas propostas de biopolítica; por fim, tais leituras serão movimentadas a partir de propostas metodológicas que dão preferência à "um uso" dos textos de Foucault na perspectiva da "caixa de ferramentas" e dos "textos-bombas", realizando uma leitura que se apoia no potencial crítico das formulações do filósofo francês.

Palavras-chave: Foucault, biopolítica, pandemia

\begin{abstract}
Philosophers Giorgio Agamben and Roberto Esposito mobilized their conceptions of biopolitics to express their opinion about the SARS-CoV-2 virus pandemic. The purpose of this article is to make a Foucaultian reading of these interventions. Our proposal is based on three moments: an analysis of the concept of biopolitics based on Foucault's courses at the Collège de France; an analysis of Agamben and Esposito's interventions in the light of their biopolitical proposals; and finally, such readings will be based on a methodological proposal that gives preference to "the use" of Foucault's texts in the perspective of the "toolbox" and "bomb texts", making a reading that is based on the critical potential of French philosopher's formulations.
\end{abstract}

Keywords: Foucault, biopolitics, pandemic

\section{Introdução}

O objetivo de nossa discussão neste artigo é abordar dois assuntos que, imbricados um ao outro, dominaram o primeiro semestre de 2020: a pandemia do vírus SARS-CoV-2 e a operacionalização analítica a partir do conceito de biopolítica, difundido por Michel Foucault nos últimos anos da década de setenta e explorado por vários autores que seguiram no caminho das hipóteses levantadas pelo filósofo francês, como Giorgio Agamben e Roberto Esposito.

Com o problema da pandemia imposto a nós, e também com a repercussão que ela causou no 
conceito de biopolítica, o campo acadêmico presenciou inúmeros pensadores e cientistas que formularam perspectivas, hipóteses e possibilidades em relação aos sintomas da pandemia e suas consequências na organização social, econômica, política e cultural de nosso mundo ${ }^{1}$. De forma geral, vivemos uma situação de formulação e aplicação de novas dinâmicas de trabalho, produção, consumo e, principalmente, das relações sociais entre os indivíduos.

Nesse grande emaranhado de produção literária e científica sobre o problema da pandemia em face das relações entre formas de governo e seus governados, o conceito de biopolítica teve seu "momento de destaque", aparecendo em grande escala nas intervenções e reações de diversos pensadores. Podemos dizer, de forma mais descontraída, de que a biopolítica foi parar na "boca do povo". 2

Porém, não se pode dizer que o florescimento de diversas análises biopolíticas acerca da pandemia é um espanto ou uma novidade para aqueles que se dedicam ao exercício filosófico. Por mais que a "passagem" de Foucault pelo conceito não seja tão extensa - em relação a outros conceitos trabalhados pelo pensador francês -, tomando sua elaboração mais densa em Segurança, território, população (2008b) e Nascimento da biopolítica (2008a), a importância da análise em termos biopolíticos não deve ser descartada.

Nildo Avelino (2012) nos propõe duas formas de "ler Foucault": uma delas seria aquela que ele denomina como "forma do texto"; a outra, é aquela dos "efeitos da crítica". Nessa primeira forma, o essencial gira em torno da preocupação com o conjunto da obra, exercendo um criterioso processo de classificação das entrevistas, cursos, seminários e outros pronunciamentos públicos.

Já na forma dos "efeitos da crítica", a preocupação não repousa em torno de uma unidade para os escritos, mas antes, sobre os procedimentos e efeitos políticos que o conteúdo crítico de tal aula, seminário, curso ou entrevista possa provocar, nos fornecendo ferramentas de análise para nosso cotidiano e ampliando os limites das problematizações concernentes ao pensamento filosófico ${ }^{3}$.

Desta maneira, pensando no campo temático e problemático do biopoder e da biopolítica, daríamos menos importância aos deslocamentos pelos quais a hipótese do poder e suas tessituras na definição conceitual de Foucault vão ocorrendo ${ }^{4}$. A proposta do efeito crítico é suscitar novas problemáticas em relação ao cotidiano, ao que nós somos e sobre aquilo que fizeram de nós. Assim, de forma alguma poderia se pensar que tal movimento seria um engessamento do conceito. O objetivo desse efeito crítico é totalmente o

1 Cf. Sopa de Wuhan (2020), coletânea de artigos de diversos filósofos sobre a pandemia.

2 Não só o conceito de biopolítica adentrou o espaço da circulação em massa, mas também suas "variantes", se assim podemos classificar. 0 conceito de necropolítica, elaborado por Achille Mbembe (2018), também foi bastante operacionalizado e se apresenta em diversas discussões, em uma parceria com as formulações de Michel Foucault sobre racismo de Estado, realizadas na aula de 17 de março de 1976 de Em defesa da sociedade (2005).

3 Algumas ressalvas são necessárias em relação ao argumento do "efeito da crítica" e da "forma do texto". Devido ao formato de artigo, optamos por fazê-las em rodapé. Nosso objetivo ao recorremos à essa referência não é desqualificar o que seria a "forma do texto". O trabalho realizado pelos comitês científicos é de extrema importância no avanço dos estudos sobre Foucault, e não se pode pensar em um trabalho que não recorra a tal forma. Exemplo disso é a coletânea Dits et ecrits (1994) ou Les aveux de la chair (2018), publicações mais ou menos recentes e que, sendo elaboradas postumamente, dependeram da atividade de um comitê de pesquisadores. O que objetivamos em levantar essas "duas formas" de ser ler Foucault é pavimentar um caminho para novas possibilidades analíticas a partir das reflexões que podemos encontrar no vasto conjunto plural que totaliza sua obra. Se Foucault desejou que seus textos fossem bombas ou ferramentas, devemos nos atentar aos estilhaços das explosões e as pluralidades funcionais das mais diversas ferramentas que já foram e das que ainda podem ser fabricadas a partir de sua obra.

${ }^{4}$ Referimo-nos aqui a um certo caminho que pode ser pensado acerca da problemática do poder em Foucault. De uma dinastia do poder, passa-se para uma analítica do poder, dando ênfase nas relações dos micropoderes e estabelecendo dois polos de atuação do poder, a saber, aquele da anátomo-política e o da biopolítica. Após essa análise da biopolítica, Foucault passará àquilo que talvez seja sua hipótese mais original em relação às tessituras do poder, que é o conceito de governamentalidade e o problema do governo de si e dos outros. 
contrário: compreender a operacionalização de um conceito a partir de uma situação e um contexto específico, que na maioria das vezes nada tem a ver com o locus de "surgimento e elaboração" do conceito.

É de extrema importância que não nos esqueçamos da similaridade entre esses "efeitos da crítica" e aquilo que Foucault desejou: que seus livros, seus escritos, suas palavras, fossem usados como uma caixa de ferramentas ${ }^{5}$. Nesse estilo particular, o filósofo francês também desejou que seus livros pudessem ser vistos como "textos-bombas, como fogos de artifícios".

À vista disso, nosso artigo se desenvolve em três momentos: uma descrição sobre as formulações que Foucault realiza sobre o conceito de biopolítica; a relação entre os comentários de Agamben e Esposito sobre a pandemia e respectivos conceitos de biopolítica; e, por fim, uma leitura foucaultiana sobre os posicionamentos expostos pelos filósofos italianos a partir da ideia de "efeitos da crítica" e da "caixa de ferramentas".

\section{A biopolítica em Foucault}

$\mathrm{Na}$ aula de 17 de março de 1976 do curso Em defesa da sociedade, Foucault nos fala sobre o conceito de biopolítica. De certa forma, é nessa aula que o conceito de biopolítica será apresentado em um contexto mais amplo do que aquele da medicina social, já descrito por Foucault em 19747. Para apresentar essa nova noção, o filósofo recorre à formulação clássica do poder soberano, discriminando-a em relação ao que seria o

${ }^{5}$ Em uma entrevista realizada em janeiro de 1975, Foucault define o uso de seus livros - e acreditamos que os cursos, entrevistas, seminários e palestras também podem ser incluídos nesta forma de uso - como caixas de ferramentas. "Meu discurso é, evidentemente, um discurso de intelectual e, como tal, opera nas redes de poder em funcionamento. Contudo, um livro é feito para servir a usos não definidos por aquele que o escreveu. Quanto mais houver usos novos, possíveis, imprevistos, mais eu ficarei contente. Todos os meus livros, seja História da loucura seja outro podem ser pequenas caixas de ferramentas. Se as pessoas querem mesmo abri-las, servirem-se de tal frase, tal ideia, tal análise como de uma chave de fenda, ou uma chave-inglesa, para produzir um curto-circuito, desqualificar, quebrar os sistemas de poder, inclusive, eventualmente, os próprios sistemas de que meus livros resultaram... pois, tanto melhor!" (FOUCAULT, 2006a, p. 52)

6 Pode-se dizer que existe uma relação paradoxal entre a caixa de ferramentas e os textos-bombas. Foucault, em uma informal conversa com alunos durante maio de 1975 - aproximadamente três meses após à afirmação da caixa de ferramentas - diz: "O ideal não é fabricar ferramentas, mas construir bombas, porque, uma vez utilizadas as bombas que construímos, ninguém mais poderá se servir delas. E devo acrescentar que meu sonho, meu sonho pessoal, não é exatamente o de construir bombas, pois não gosto de matar pessoas. Mas gostaria de escrever livros-bombas, quer dizer, livros que sejam úteis precisamente no momento em que alguém os escreve ou os lê. Em seguida, eles desapareceriam. Esses livros seriam de tal forma que desapareceriam pouco depois de lidos ou utilizados. Os livros deveriam ser espécies de bombas e nada mais. Depois da explosão, se poderia lembrar às pessoas que esses livros produziram um belíssimo fogo de artifício. Mais tarde, os historiadores e outros especialistas poderiam dizer que tal ou tal livro foi tão útil quanto uma bomba, e tão belo quanto um fogo de artifício" (FOUCAULT, 2006a, p. 266). Se Foucault recusa a possibilidade das ferramentas algum tempo depois, isto cabe à leitura da "forma do texto". Em nossa proposta, seguindo a linha da leitura do "efeito crítico", poderíamos dizer o seguinte: nem ferramentas e nem bombas, mas antes, ferramentas-bombas.

7 Em 1974, em conferência na UERJ, Foucault fala pela primeira vez em público sobre a biopolítica. Nesse momento, sua análise joga luz nas relações da medicina social e em questões pertinentes a esse campo especifico de atividade da ciência médica. "Nessa conferência, a definição de biopolítica é apresentada em sentido exclusivamente associado à medicina social" (MENEZES, 2014, p. 51). Para uma leitura mais detalhada da obra de Foucault sobre esse momento de apresentação da biopolítica, cf. A trajetória das artes de governar em Michel Foucault (2014) de Leandro Alves Martins de Menezes. Em nosso trabalho, não nos dedicaremos a esta conferência de Foucault, já que a apresentação de biopolítica que interessa ao nosso trabalho está localizada em Em defesa da sociedade, $A$ vontade de saber e Segurança, território, população. Ainda assim, em determinado momento de Em defesa da sociedade, Foucault passa por questões da medicina social, já que o surgimento de tecnologias biopolíticas se deu no âmbito das ciências da vida. 
biopoder ou a biopolítica. Também em $A$ vontade de saber, no último capítulo que compõe o tomo, Foucault joga luz na questão do poder soberano e de "novas" formas de exercício do poder.

Porém, antes de nos debruçarmos sobre a noção de biopolitica e biopoder, é fundamental determo-nos na linha trilhada por Foucault em relação ao poder soberano e à teoria clássica da soberania.

O poder soberano é, de fato, um poder que tem direito de vida e de morte (FOUCAULT, 2010, p. 147; 2005, p. 286). O soberano terreno, aquele do poder régio, tem um direito natural sobre a vida de seus súditos. Esse direito é uma herança da patria potestas romana (FOUCAULT, 2010a, p. 147), formulação que diz respeito ao direito do pai em relação à vida de seus filhos e escravos. Como o pai havia "gerado" essas vidas, ele teria direito de suprimi-las, eliminá-las. Teria direito sobre a vida e a morte daqueles que eram sua propriedade e estavam sob domínio de seu comando.

Assim é com o soberano e seus súditos. O soberano tem direito sobre a vida daqueles que lhe servem. E esse direito sobre a vida se manifesta justamente pelo poder de causar a morte. Paradoxal, porém é um poder assimétrico. É um poder que se exerce fazendo morrer e deixando viver. Assim, o direito à vida ocorre ao soberano justamente por ele ser aquele que causa a morte e interrompe a vida. Isso coloca a vida e a morte em uma série de fenômenos que não são naturalizados. Vida e morte, ao serem exercidas pelo poder do soberano, estão localizadas dentro do poder político:

O direito que é formulado como "de vida e morte" é, de fato, o direito de causar a morte ou de deixar viver [...] O poder era, antes de tudo, nesse tipo de sociedade, direito de apreensão das coisas, do tempo, dos corpos e, finalmente, da vida; culminava com o privilégio e se apoderar da vida para suprimi-la (FOUCAULT, 2010, p. 148).

É assim, então, que ocorria o funcionamento do direito de vida e morte na teoria clássica da soberania. "Cabia ao soberano a prerrogativa de matar, de maneira espetacular, os que ameaçassem seu poderio, e deixar viver os demais” (PELBART, 2013, p. 25).

A morte, nessa trama histórica do poder soberano, é um evento de grande ritualização, no qual aquele que morre desloca-se de um poder terreno para o poder celeste (FOUCAULT, 2005, p. 294-295). É uma transferência em relação à "instância de julgamento", na qual se passa do direito de vida e de morte para o direito da vida eterna ou da danação eterna. Outrora, a partir do fim do século XVIII, a morte será progressivamente alocada no âmbito mais privado, íntimo, e até vergonhoso da vida.

A grande transformação anunciada por Foucault é que esse poder soberano, essa forma de poder que se incumbia de faz̧er morrer e deixar viver se transformará em fazer viver e deixar morrer. Ocorre um deslocamento no direito político, responsável por essa metamorfose no direito de vida e de morte ${ }^{8}$. A instância de ação do poder não será tão mais sobre a morte do que sobre a vida. Assim, como aponta Foucault (2010a, p. 148), "Ora, a partir da época clássica, o Ocidente conheceu uma transformação muito profunda desses

\footnotetext{
8 Foucault revela que seu interesse em relação à transformação do direito de vida e de morte não se dá no contexto de uma teoria política, mas sim, no "[...] nível dos mecanismos, das técnicas, das tecnologias de poder (FOUCAULT, 2005, p. 288). Assim, Foucault faz uma brevíssima exposição em relação às transformações no campo da filosofia política, mostrando que, a partir do século XVII e de forma mais acentuada no século XVIII, os juristas passam a colocar a vida como algo que está fora do poder do soberano. No momento em que se estabelece o contrato social, qual é a motivação dos que delegam um soberano? É a motivação da vida. Aqueles que estabelecem o contrato temem por sua vida, querem suprimir o perigo. Ou seja, eles instituem um soberano para que ele possa estabelecer condições nas quais seja possível viver. Assim, a vida é fundadora do direito soberano. Desta forma, "Não deve a vida ficar fora do contrato, na medida em que ela é que foi o motivo primordial, inicial e fundamental do contrato? (FOUCAULT, 2005, p. 288)".
} 
mecanismos de poder". O poder passa a se exercer por outras formas, com funções que incitam reforço, controle, organização, vigilância, adestramento e regulação da vida (FOUCAULT, 2010a, p. 148). É um poder que busca produzir uma força de vida e não mais deteriorá-la. De forma que, para produzir forças, ele passe a gerir a vida:

[...] um poder destinado a produzir forças, a fazê-las crescer e a ordená-las mais do que a barrá-las, dobrálas ou destruí-las. Com isso, o direito de morte tenderá a se deslocar ou, pelo menos, a se apoiar nas exigências de um poder que gere a vida e a se ordenar em função de seus reclamos (FOUCAULT, 2010a, p. 148, grifo nosso).

A partir dessa transformação que inaugura o faz̧er viver e deixar morrer, as tecnologias e estratégias de poder vão se desenvolver em dois novos - diferentes, porém complementares - polos de ação do exercício de poder sobre a vida dos homens. O poder soberano que exercia seu poder pelos suplícios ${ }^{9}$, causando a morte, se dissipa, dando espaço às novas tecnologias de poder que buscarão um prolongamento da vida. Para Foucault, essa transformação pode ser vista da seguinte maneira:

O homem, durante milênios, permaneceu o que era para Aristóteles: um animal vivo e, além disso, capaz de existência política; o homem moderno é um animal em cuja política sua vida de ser vivo está em questão (FOUCAULT, 2010a, p. 156).

Assim, dessa nova forma de exercício de poder, como dito, surgem dois polos de atuação. Um é aquele que Foucault denomina de anátomo-política (FOUCAULT, 2010a, p. 151). Nesse primeiro plano, no século XVII e início do século XVIII, vê-se o surgimento das técnicas disciplinares, focalizadas no corpo individual. É a ideia do corpo como uma máquina (FOUCAULT, 2010, p. 151), tendo suas forças maximizadas, racionalizadas, exercitadas e disciplinadas para que se possa extrair máximo rendimento em relação ao trabalho e a disciplina. Objetiva-se uma sujeição dos corpos individuais. Não se pode dizer que esse exercício de poder não busca reger uma multiplicidade de homens, conquanto, esse número de sujeitos deve estar inscrito em "corpos individuais que devem ser vigiados, treinados, utilizados, eventualmente punidos" (FOUCAULT, 2005, p. 289).

Já o outro polo, a outra forma de exercício de poder que fundamenta o direito de vida e morte que faz viver e deixar morrer é aquela denominada por Foucault de biopolitica, ou simplesmente, biopoder (FOUCAULT, 2005, p. 289; 2010a, p. 152). Durante o final do século XVIII, as estratégias referentes a esse exercício de poder passam a se apresentar. Em relação ao outro polo de exercício de poder, aquele disciplinar, a biopolítica causa imbricações, se integrando e modificando parcialmente a anátomo-política. Segundo Foucault (2005, p. 298), o aparecimento posterior da biopolítica em relação à anátomo-política revela mais sobre o desenvolvimento das tecnologias de poder do que sobre qualquer especulação acerca de uma escala evolutiva das formas de poder. Uma tecnologia de poder não exclui a outra ${ }^{10}$, mas sim, vai “[...] incrustando-se

\footnotetext{
9 Referimo-nos aqui a obra Vigiar e Punir (1999), originalmente publicada em 1975. Um ano antes do curso Em defesa da sociedade e de $A$ vontade de saber, ambos de 1976, Foucault já demonstrava essa transferência do poder soberano para outras formas de poder. Também encontramos referências a essas novas tecnologias de poder, principalmente a anátomo-politica, nos cursos da primeira metade da década de setenta, como A sociedade punitiva (2015), O poder psiquiátrico (2006b) e Os anormais (2010b).

10 Edgard Castro (2015) afirma que em A vontade de saber, Foucault é ambíguo em relação ao poder soberano e ao biopoder. Segundo Castro, "Às vezes fala de substituição e às vezes de complementaridade entre ambos os poderes. Em todo caso, uma coisa é clara: não se trata de que de um golpe um desapareceu por completo e o outro ocupou seu lugar; ao contrário, algumas das considerações mais relevantes de Foucault sobre a relação entre soberania e
} 
efetivamente graças a essa técnica disciplinar prévia (FOUCAULT, 2005, p. 289). Dessa forma, a análise do filósofo se direciona em uma perspectiva de remanejamentos estratégicos dos dispositivos de controle ${ }^{11}$. $\mathrm{O}$ poder exercido na ótica da soberania torna-se ineficiente a partir de certos processos econômicos e políticos, de forma que, para recuperar os detalhes que havia perdido, acomoda-se sobre as tecnologias disciplinares do corpo. Foucault afirma que esta forma de acomodação dos detalhes foi “[...] mais fácil, mais cômoda de realizar” (FOUCAULT, 2005, p. 289). Após esse primeiro nível, ocorre uma segunda acomodação de detalhes, que irá se deter no nível da biopolítica. Isto nos confirma que tais formas de exercício de poder se mesclam, atuando simultaneamente sobre os indivíduos.

Então, finalmente nos perguntamos: o que é a biopolítica?

\section{Biopolítica e população}

Segundo Foucault, na aula de 17 de março de 1976 em Em defesa da sociedade, a biopolítica define-se por sua direção ao homem ser vivo, homem-espécie. Essa espécie, esses homens, convivendo diariamente em espaços compartilhados e simultâneos, enfrentam processos que são intrínsecos à própria vida. A biopolítica surge com a preocupação do nascimento, da morte, da doença, da higiene, da produção. Ela terá como objeto um conjunto de indivíduos que é integralmente afetado pelos mesmos acontecimentos.

Diferentemente da anátomo-política que tem função de individualizar o homem, isolando o corpo individual em uma circunscrita disciplina, a biopolítica busca aglutinar o conjunto de homens em um só corpo: o corpo da população. (FOUCAULT, 2005, p. 292-293). Segundo Foucault (2005, p. 292), nem a teoria do direito e nem a prática disciplinar tinham conhecimento do elemento população. Na teoria do direito, os elementos conhecidos eram indivíduos e sociedade: indivíduos responsáveis pelo contrato - de forma direta ou implícita - e sociedade fundada pelo contrato. Já na prática disciplinar, conhecia-se o indivíduo e seu próprio corpo.

A biopolítica será responsável pela constituição deste novo elemento: a população. Um conjunto de homens é estabelecido pelo exercício de poder de mecanismos reguladores (FOUCAULT, 2010, p. 152), objetivando um gerenciamento da vida dessa aglutinação de indivíduos:

São esses processos de natalidade, de mortalidade, de longevidade que, justamente na segunda metade
do século XVIII, juntamente com uma porção de problemas econômicos e políticos (os quais não re-
tomo agora), constituíram, acho eu, os primeiros objetos de saber e os primeiros alvos de controle dessa
biopolítica. É nesse momento, em todo caso, que se lança mão da medição estatística desses fenômenos
com as primeiras demografias. É a observação dos procedimentos, mais ou menos espontâneos, mais
ou menos combinados, que eram efetivamente postos em execução na população no tocante à natali-
dade; em suma, se vocês preferirem, o mapeamento dos fenômenos de controle dos nascimentos tais
como eram praticados no século XVIII (FOUCAULT, 2005, p. 290).

biopoder concerne, precisamente, ao modo em que ambos se entrelaçam, por exemplo, a propósito da sexualidade." (CASTRO, 2015, p. 104)

11 Segundo Foucault (2017) dispositivos são redes constituídas a partir de conjuntos heterogêneos formados por leis, instituições, práticas regulamentares, discursos, medidas administrativas e etc. Esses elementos heterogêneos formam o dispositivo e se articulam de maneira que correspondam a objetivos de cada momento histórico, e isso inclui remanejamentos estratégicos. "[...] o dispositivo se constitui como tal e continua sendo dispositivo à medida que engloba um duplo processo: por um lado, processo de sobredeterminação funcional, pois cada efeito, positivo ou negativo, desejado ou não, estabelece uma relação de ressonância ou de contradição com os outros, e exige uma rearticulação, um reajustamento dos elementos heterogêneos que surgem dispersamente; por outro lado, processo de perpétuo preenchimento estratégico" (FOUCAULT, 2017, p. 365) 
O biopoder surge, então, nesse contexto de lacunas em relação ao exercício de poder que é realizado sobre um conjunto de indivíduos. A natalidade, a reprodução e a morbidade são fenômenos intrínsecos ao funcionamento do corpo social, de forma que o Estado passe a gerir a vida desses indivíduos aglutinados em um conjunto, estabelecendo estratégias e técnicas de controle para determinadas situações. O esquadrinhamento realizado pela anátomo-política - o poder disciplinar - não é eficiente em relação aos problemas da população, ou, ao problema da cidade (FOUCAULT, 2005, p. 292), daí o biopoder.

Um dos exemplos fornecidos por Foucault em relação ao gerenciamento da vida dos homens, diz respeito às epidemias e endemias (FOUCAULT, 2005, p. 290-291). No direito de vida e de morte soberano, aquele que faz, morrer e deixa viver, enfrenta-se o problema da morte iminente dos homens por uma epidemia, que é uma situação temporária de morte multiplicada. Já no direito de vida e morte que faz viver e deixa morrer - característico da anátomo-política e da biopolítica, das sociedades pós-soberania - o problema que se enfrenta são as endemias. O exercício de poder já não se preocupa com situações temporárias, aquelas circunscritas do indivíduo isolado, mas sim, com todo um grupo de indivíduos na generalidade de suas vidas. Quer-se controlar "[...] a forma, a natureza, a extensão, a duração, a intensidade das doenças reinantes numa população.” (FOUCAULT, 2005, p. 290). Assim, o problema da doença é algo latente na dinâmica da população, devendo ser abordado cotidianamente e não apenas em momentos de morte generalizada, como era com o direito soberano de vida e morte atingido pela fatalidade da doença e pelo estatuto da epidemia. Portanto, a biopolítica busca um controle majoritário sobre a vida, um estado de equilíbrio global sobre a população, “[...] algo como uma homeostase: a segurança do conjunto em relação aos seus perigos internos" (FOUCAULT, 2005, p. 297), em suma:

$[\ldots]$ a doença como fenômeno da população: não mais como a morte que se abate brutalmente sobre a vida - é a epidemia - mas como a morte permanente, que se introduz sorrateiramente na vida, a corrói perpetuamente, a diminui e a enfraquece (FOUCAULT, 2005, p. 291).

Além dessa problemática que se preocupa com a noção de endemia - ou seja, que revela um caráter de preocupação com problemas intrínsecos ao conjunto populacional - outro campo de intervenção biopolítica é aquele relacionado aos problemas universais e acidentais. São mecanismos reguladores que geram seguros, poupanças, previdências, seguridade (FOUCAULT, 2005, p. 291). Desta forma, pode-se controlar fenômenos como a longevidade e mortalidade de uma população, acidentes singulares das mais diversas particularidades que pode se abater sobre os indivíduos, tipos de anomalias que se manifestam em grupos, dentre outras séries de acontecimentos singulares. Dessa forma, pensar um exercício de poder biopolítico é também pensar em um campo de intervenções que está conectado às demandas particulares de cada indivíduo. Constitui-se um conjunto de homens e cria-se um conhecimento específico sobre cada um deles. Para Foucault, essa configuração específica da biopolítica que institui o funcionamento de dispositivos de regulação e normatização, é o que classifica um conjunto de tecnologias como dispositivos de segurança.

A biopolítica e seus mecanismos reguladores exercem uma forma de poder que além de buscar gerenciar a população, pretendem também criar um meio no qual essa população se localiza. Assim, os dispositivos de segurança irão atuar nos âmbitos sociais e econômicos, tratando de organizar uma circulação, suprimir os perigos, focalizar a boa e a má circulação de forma que se maximize a boa circulação em função de diminuição da má. Não se trata de estabelecer fronteiras, estritamente como no modelo disciplinar. Querse, essencialmente, garantir e possibilitar as circulações as pessoas, mercadorias, enfim, de tudo o que está localizado no meio (FOUCAULT, 2008b, p. 40). Desta forma, podemos dizer que os dispositivos de 
segurança de uma biopolítica exercem uma forma de regulação sobre aquilo que se encontra e circula no meio.

Tanto as tecnologias anátomo-políticas quanto as biopolíticas estão presentes no meio que se encontra a população e exercem dominação sobre seus objetos, respectivamente, indivíduo e população. Do lado do indivíduo, tem-se a disciplina que é aplicada e deve ser internalizada. Do lado da população, tem se a regulamentação. Para esta configuração de sociedade na qual anátomo-politica e biopolítica se cruzam nas formas de exercício de poder, Foucault (2005, p. 302) dirá que se vê uma sociedade de normalização.

A norma é o elemento que dá possibilidade de circulação entre a disciplina e a regulamentação, permitindo, de uma só vez, controlar o âmbito disciplinar do corpo e os acontecimentos relativos à população. Com isso, não devemos ver uma sociedade de normalização como expressão de personificação e maximização estritamente disciplinar, momento de exacerbação e controle generalizado das tecnologias anátomo-politicas, mas sim como uma sociedade na qual se cruzam disciplina e regulamentação em relação ao controle da vida:

A norma é o que pode tanto se aplicar a um corpo que se quer disciplinar quanto a uma população que se quer regulamentar [...] A sociedade de normalização é uma sociedade em que se cruzam, conforme uma articulação ortogonal, a norma da disciplina e a norma da regulamentação (FOUCAULT, 2005, p. $302)$.

Isso, colocado em um plano mais generalizado sobre as formas de regulamentação biopoliticas, resulta na seguinte situação: controla-se a população como um todo e é ela o objeto de análise. A população e os acontecimentos que a permeiam e a atingem são pertinentes como objetivo. Porém, os grupos de indivíduos, as séries individuais, as multiplicidades de indivíduos são apenas ferramentas. Tais ferramentas objetivam ser pertinentes como instrumentos de ação na população. Assim, temos dois níveis: o nível da população e o nível dos indivíduos. Para se atingir o nível da população, modificando-a juntamente de seus acontecimentos, emerge-se uma ação no nível dos indivíduos. Aí está a questão da norma. A circularidade entre a regulamentação biopolítica e a disciplina da anátomo-política dão condições para que se conduzam indivíduos e população na "linha ideal".

É desta forma que Foucault vê e classifica os exercícios de poder nas sociedades modernas: um conjunto de saberes e práticas que, operados simultaneamente, produzem um indivíduo que é disciplinado pelas práticas anátomo-políticas e regulado pelas práticas biopolíticas.

\section{Agamben e o problema das técnicas que nos regerão}

No dia 26 de fevereiro de 2020, Giorgio Agamben (2020a) publicou um artigo intitulado L'invenz̧ione di un'epidemia. Agamben justificou o seu ceticismo em relação aos dados recolhidos pelo Consiglio Ną̧ionale delle Ricerche, que dizia que na Itália não havia uma pandemia e que, na maioria dos casos, as pessoas infectadas apenas teriam sintomas leves. Além disso, esse relatório previa que apenas 4\% dos pacientes precisassem de internação nos leitos hospitalares de terapia intensiva.

Diante dessas informações, Agamben questionou o porquê do clima de pânico causado pelas autoridades políticas e pela imprensa. Para Agamben, todo esse alarmismo estava "provocando um verdadeiro e próprio estado de exceção" (AGAMBEN, 2020a), já que as condições normais de vida das pessoas tinham sido suspensas. 
No portal italiano quodlibet, Agamben escreveu mais onze textos depois de sua primeira intervenção ${ }^{12}$. Em todos eles, pode-se dizer sem dúvidas que o mesmo movimento espiral paira: a possibilidade de um estado de exceção permanente, que estaria sendo implantado paulatinamente a partir do desenvolvimento de novas técnicas e tecnologias desenvolvidas pelos dispositivos disciplinares e biopolíticos; quase como um pedido de resistência para os indivíduos, incitando-os, provocando-os, para algumas reflexões que podem ser consideradas incômodas, perigosas, e para alguns, até um “atestado de suicídio". Quem se exporia para a morte e recusaria, por exemplo, o isolamento social em nome de uma afirmação da invenção de uma pandemia? Afinal, tal técnica se mostrava progenitora em relação aos dados de combate ao vírus e sua propagação. Então, o que propunha Agamben?

Acreditamos que um texto publicado em 23 de março e intitulado Sobre a técnica e a arte ${ }^{13}$ (AGAMBEN, 2020b), possa ser um bom instrumento para pensarmos os caminhos escolhidos por Agamben em seus "doze textos pandêmicos". Em nenhum momento desse pequeno texto, o assunto do vírus ou da pandemia aparece. Pandemia e biopolítica poderiam ser classificados como temas muito distante dos objetivos que Agamben está propondo nessa reflexão. Mas não nos parece que é esse o caso.

Nesse pequeno texto, Agamben nos dirá que todos os viventes, de uma maneira ou de outra, tem técnicas específicas em seu cotidiano para manutenção de seus hábitos vitais, aqueles de caráter primárioorgânico. Pensando da forma mais simples possível: nós, como seres humanos, não poderíamos viver sem o sol, sem a exposição de nosso órgão dermático aos raios solares. Tal exposição produz vitaminas, ajuda na regulação do sono e tem diversos outros efeitos no corpo, podendo ser benéficos ou não. Para esse tipo de técnica, para tal forma de produção de energia, se aplica a terminologia endossomática. Ou seja, as técnicas de impulsos primário-orgânicas, como exposição ao sol, tomar água, digestão de alimento para produção de calorias, evacuação de fezes, dentre outras, são técnicas de produção de energia endossomática.

Porém, as técnicas endossomáticas não são as únicas que estão presentes no cotidiano dos homens. Segundo Agamben (2020b), o homem foi adiante em um padrão exossomático do desenvolvimento das técnicas sobre a vida, expulsando as técnicas vitais para fora de seu corpo e as solidificando em tecnologias artificiais, exteriores ao corpo do homem. Em relação a tais tecnologias artificiais, Agamben (2020b) diz que, assim, “[...] os instrumentos técnicos seriam apenas o desenvolvimento, em forma de prótese, de capacidades funcionais do organismo que são projetadas fora do corpo”. É dessa forma que se pode pensar no desenvolvimento e produção de um edifício exossomático de tecnologias e técnicas de produção de energia. Porém, não se deve ignorar que o caráter de produção exossomático obrigatoriamente se apoia na produção enérgica endossomática.

Isso resulta em um processo que nos leva até a seguinte afirmação: não existe uma divisão entre técnica e vida. Pensar a tecnogênese não pode estar deslocado do movimento de reflexão sobre a antropogênese. A técnica integra a vida humana, faz parte das "[...] práticas vitais do vivente artista" (AGAMBEN, 2020b). Ou seja, não se pode pensar o homem e sua vida sem pensar nas técnicas (artes) que ele emprega para a manutenção de sua existência.

Porém, a projeção exossomática, ou seja, uma produção externa das funções dos órgãos corpóreos, gera uma desativação dos dispositivos endossomáticos. O plano de desenvolvimento das técnicas e tecnologias exossomáticas entra em um campo de valoração que se institui num movimento de detrimento das técnicas e tecnologias endossomáticas. Diferentemente do animal, que adapta suas funções corpóreas às condições

12 Até o momento de confecção de nosso artigo, que data de 31/03/2020.

13 Publicado originalmente no portal italiano Laboratorio Archeologia Filosofica. 
naturais de seu meio, o homem desativa essas mesmas funções para confiar aos instrumentos artificiais, aqueles exossomáticos. Nas palavras de Agamben:

Utilizando-me de um conceito forjado por Gunther Anders, prefiro falar, a propósito disso, de um "desnível prometeico", isto é, de uma separação crescente entre o homem e o mundo de seus produtos, o que torna, em última análise, o homem incapaz de estar à altura das próprias produções técnicas e, portanto, de dominá-las. Podemos dizer que hoje esse desnível chegou ao ponto de máxima tensão. O homem como indivíduo endossomático, também pelo progressivo atrofiamento de suas capacidades internas, parece totalmente incapaz de assumir o controle da esfera exossomática dos produtos por ele criados. Dito de outra forma, a cultura humana parece ter sido de todo separada e tornada autônoma em relação à natureza humana (AGAMBEN, 2020b).

A partir disso, Agamben tocará em um ponto caro à extensão de sua obra: o problema da função e do uso ${ }^{14}$. A problemática da técnica exossomática e do princípio de desativação dos órgãos corpóreos faz com que o homem não tenha mais controle sobre as funções de suas ferramentas, em um movimento no qual a própria ferramenta distancia-se de sua causa instrumental. Ou seja, do martelo que fornecia para a mão a possibilidade de martelar, agora se tem o martelo que exerce a "[...] função-batedora que se autonomiza da mão e pode assumir as mais variadas formas mecânicas [...] Podemos, assim, dizer que o que vemos é a transformação do uso em função” (AGAMBEN, 2020b).

Essa proeminência da função em detrimento do uso, para Agamben, gera uma experiência sem resultados éticos para os sujeitos que estão nela implicados. E aqui encontramos um importantíssimo ponto em todo o projeto Homo sacer e também nos textos publicados no quodlibet: a vida nua. Essa vida nua é aquela vida que é pensada não apenas destituída de suas formas, mas também de suas técnicas. Tal vida nua seria uma vida deslocada da possibilidade de formulação de uma arte da existência:

A tese foucaultiana deverá, então, ser corrigida ou, pelo menos, integrada, no sentido de que aquilo que caracteriza a política moderna não é tanto a inclusão da Zoé na pólis, em si antiguíssima, nem simplesmente o fato de que a vida como tal venha a ser um objeto eminente dos cálculos e das previsões do poder estatal; decisivo é, sobretudo, o fato de que, lado a lado como o processo pelo qual a exceção se torna em todos os lugares a regra, o espaço da vida nua, situado originariamente à margem do ordenamento, vem progressivamente a coincidir como o espaço político, e exclusão e inclusão, externo e interno, bios e zoé, direito e fato entram em uma zona de irredutível indistinção (AGAMBEN, 2002, p. 16).

É aqui que nos parece se localizar o problema para Agamben em relação aos efeitos da pandemia: estaríamos todos em uma situação na qual não existe mais possibilidade de resistência face aos dispositivos que operam e determinam os caminhos da vida?

[...] a radical transformação da política em espaço da vida nua (ou seja, em um campo) legitimou e tornou necessário o domínio total. Somente porque em nosso tempo a política se tomou integralmente biopolítica, ela pôde constituir-se em uma proporção antes desconhecida como política totalitária (AGAMBEN, 2002, p.126).

Nessa trama histórica, a desativação de si mesmo é um problema para o homem. Cada vez mais ele se desconecta de si mesmo, resultando em uma hipertrofia de sua consciência, "[...] a qual se transforma em um órgão que pretende controlar e gerir o patrimônio exossomático da humanidade, mas que não o pode fazer, porque na realidade está totalmente no interior desse patrimônio" (AGAMBEN, 2020b). Retomando

14 Sobre a problemática do uso, cf. O uso dos corpos (2017). 
rapidamente Foucault em sua conferência Qu'e est-ce que la critique (1990), de quais formas e de quais maneiras aceitamos ser governados?

Tal problemática não está deslocada da biopolítica em Agamben, mas sim, intimamente conectada. De quais formas iremos levar nossas vidas após a pandemia, em um mundo cada vez mais digitalizado e televisionado, com a proliferação dos modelos de ensino a distância e de home office, com práticas ininterruptas de distanciamento social, dinâmicas de laços familiares e de luto radicalmente alteradas, crises econômicas, aumento das taxas de adoecimento psíquico e diversas outras consequências que ainda estão por vir e só o tempo as apresentará para nós:

\section{Esposito e o paradigma imunitário}

Em 28 de fevereiro de 2020, dois dias após o texto de Agamben, Roberto Esposito publica um texto intitulado Curati a oltranza, onde afirma que não há dúvidas que hoje temos uma implementação plena da biopolítica, isto é, "todos os conflitos políticos atuais têm em seu centro a relação entre a política e a vida biológica" (ESPOSITO, 2020). Porém, refletindo sobre a pandemia, Esposito nos adverte que quando falamos de biopolítica, não devemos deixar de ter em conta o "caráter historicamente diferenciado dos fenômenos biopolíticos” (ESPOSITO, 2020). Em outras palavras, não se pode comparar experiências incomparáveis caindo na armadilha de anacronismos e julgamentos desqualificados. Para Esposito (2020), era um exagero afirmar que tal situação poderia colocar em causa a democracia, tese defendida por Agamben (2002) e que segue a linha de seu projeto Homo sacer, iniciado nos anos 90 e que se apoia nevralgicamente na tese do estado de exceção permanente.

Esposito pretendeu realçar que os processos de medicalização da política e de politização da medicina não tem início apenas com a pandemia. Pelo contrário, este duplo processo envolvendo a esfera política e a esfera médica está na gênese do nascimento da biopolítica (ESPOSITO, 2010). Assim, a análise preliminar de Esposito à questão da pandemia vai de encontro com a sua teoria do paradigma imunitário.

No centro da concepção da biopolítica de Esposito reside a tentativa de responder a uma questão fundamental deixada em aberto por Foucault, a saber: [...] porque é que [...] uma política da vida ameaça sempre transformar-se numa obra de morte?" (ESPOSITO, 2010, p. 23). Esposito notou que na dicotomia existente entre dois extremos interpretativos da biopolítica, "uma radicalmente negativa e outra absolutamente eufórica - [...] não fazem mais do que absolutizar [...] as duas opções hermenêuticas entre as quais Foucault nunca se resolve a fazer uma escolha de fundo" (ESPOSITO, 2010, p. 23). O enigma biopolítico para Esposito reside, assim, na possibilidade de a biopolítica passar de uma política da vida para uma tanatopolítica (ESPOSITO, 2010, p. 65). O nazismo é o paradigma de uma tanatopolítica para o filósofo italiano.

Assim, será com o conceito de imunidade que Esposito pretende resolver esse enigma biopolítico e o vazio semântico deixado por Foucault no que concerne à diferenciação entre biopolítica e biopoder. É no paradigma imunitário que Esposito enxerga a possibilidade de conciliar vida e política sem que nenhum desses dois domínios se sobreponham. Dessa forma, a "[...] imunidade não é apenas a relação que liga a vida ao poder, mas o poder de conservação da vida" (ESPOSITO, 2010, p.74). Com essa formulação, poder e vida nunca estão em planos diferentes. Pelo contrário, "não existe um poder externo à vida, assim como a vida não se dá nunca fora das relações de poder" e, assim sendo, "a política não é senão a possibilidade, ou o instrumento, de conservar viva a vida” (ESPOSITO, 2010, p.74).

O paradigma imunitário apresenta-se como uma possibilidade de articulação interna entre os dois efeitos derivados da relação entre biopoder e biopolítica: "ou o poder nega a vida ou aumenta o seu 
desenvolvimento; ou a violenta e exclui ou a protege e reproduz; ou a objectiviza ou a subjectiviza" (ESPOSITO, 2010, p.74). Essa articulação dá-se por meio de uma relação causal de tipo negativo. A imunização oferece uma proteção negativa à vida: “a vida se conserva através do poder” (ESPOSITO, 2010, p.74), da mesma forma que uma vacina é a aplicação do mesmo vírus que se pretende combater, " [...] a imunização do corpo político funciona introduzindo no seu interior um fragmento da mesma substância patogênica da qual o quer proteger [...]" (ESPOSITO, 2010, p.74-75). O poder de conservação e de destruição coexistem. A “autopreservação imunitária” (ESPOSITO, 2010, p.76) é o esforço das sociedades modernas de resistirem ao todo o tipo de ameaças internas ou externas. O processo de imunização "[...] incorpora o negativo e o positivo em uma lógica paradoxal de proteção através da exposição” (MILLS, 2017, p.89).

Contudo, essa "autopreservação imunitária" tem implicações patológicas para o funcionamento da sociedade. É fundamental, por isso, compreender a relação em Esposito dos conceitos de comunidade (communitas) e imunidade (immunitas):

Reconduzida à sua raiz etimológica, a immunitas revela-se como a forma negativa. ou privativa, da communitas: se a communitas é aquela relação que, vinculando os seus membros a um objectivo de doação recíproca, põe em perigo a identidade individual, a immunitas é a condição de dispensa dessas obrigações e por conseguinte de defesa ante os seus esforços expropriatórios (ESPOSITO, 2010, p.80).

Existe uma tensão permanente no interior do paradigma imunitário de Esposito entre a immunitas e a communitas. A comunidade consegue a sua conservação por meio da imunização que, por sua vez, põe em causa a própria natureza da comunidade. "Aquilo que é imunizado [...] é a própria comunidade, de uma forma que conjuntamente a conserva e a nega - ou melhor, a conserva através da negação do seu originário horizonte de sentido" (ESPOSITO, 2010, p.82). A concepção de comunidade de Esposito é niilista em contraponto à ideia aristotélica de uma cidade imbuída de um sentido teleológico em direção à "vida boa" que preenche a vida qualificada de seus cidadãos:

Esposito sustenta a tese que o núcleo fundamental de toda a vida e organização da comunidade é uma impropriedade: não há, na comunidade, uma comunhão por identificação; os indivíduos não se reconhecem aí como semelhantes, mas como coobrigados ao ônus do tributo devido, numa cumplicidade pela ausência, pela irrealização do próprio do sujeito e do indivíduo. Por essa razão, há uma estreita vinculação entre comunidade e o nada, ou dito ainda de outro modo, a comunidade tem uma intrigante natureza niilista, pela qual se impede a realização plena dos indivíduos, de seus partícipes em sujeitos. Nesse sentido, a comunidade nutre-se e se mantém com base num complexo processo de dessubjetivação do homem (NALLI, 2012, p. 43).

Tendo em conta a ideia de comunidade em Esposito, o processo imunitário tem implicações ontológicas, já que o "reconhecimento do eu e do outro se desfaz de tal maneira que o eu não é mais reconhecido como aquilo que deve ser protegido e não atacado.” (MILLS, 2017, p.93).

\section{A peste sonhadora}

É possível pensar que Agamben e Esposito rumam para caminhos diferentes em relação às suas intervenções sobre a problemática da pandemia. Enquanto em Agamben vê-se uma latente preocupação com o problema de uma vida digna e que se dirija por si mesma, lutando contra o estado da vida nua e fugindo de uma destituição de todas as artes e existências de viver ancoradas em uma valorização endossomática, Esposito nos aponta um caminho onde é necessário pensar qual vida, qual comunidade e qual imunidade 
iremos estabelecer após o acontecimento pandêmico de 2020, redefinindo nossos paradigmas de organização comunitária e biológica.

Mas também é possível pensar em uma união dessas duas perspectivas, de forma que uma complemente a outra, nos fornecendo novas possibilidades de enfrentar as consequências que já estão postas e aquelas que ainda irão se apresentar. Para pensarmos nessa "união" das perspectivas, em uma possível pavimentação para resolução dos problemas da pandemia, iremos mobilizar um pequeno trecho da aula de 15 de janeiro de 1975 do curso Os anormais (2010b), lecionado por Foucault. Ali, ao tratar do desenvolvimento das tecnologias positivas de poder e a diferença entre o modelo da lepra e da peste, Foucault nos invoca duas imagens referentes ao problema da peste que atinge a cidade: o sonho literário e o sonho político.

O sonho literário da peste, que segundo Foucault se estende de Tucídides até Albert Camus, opera na dimensão de uma certa liberdade e certo caos que são instituídos pela peste que assola a cidade:

[...] ameaçados pela morte que transita entre eles, abandonam sua identidade, tiram a máscara, esquecem seu estatuto e se entregam à grande depravação das pessoas que sabem que vão morrer [...] uma espécie de sonho orgiástico da peste, em que a peste é o momento em que as individualidades se desfazem, em que a lei é esquecida (FOUCAULT, 2010b, p. 40).

Diferentemente é o sonho político da peste, no qual ocorre “[...] o momento maravilhoso em que o poder político se exerce plenamente” (FOUCAULT, 2010b, p. 40). Segundo Foucault, é no momento da peste em que o poder político se exerceria de forma mais exacerbada, onde o policiamento atingiria seu ponto extremo, suprimindo toda e qualquer comunicação considerada perigosa e restringindo os contatos proibidos que, devido a peste, não podem mais ser produzidos:

A peste traz consigo, talvez, o sonho literário ou teatral do grande momento orgiástico; a peste traz consigo também o sonho político de um poder exaustivo, de um poder sem obstáculos, de um poder inteiramente transparente a seu objeto, de um poder que se exerce plenamente (FOUCAULT, 2010b, p. 41).

Quando dizemos que queremos usar o sonho político e o sonho literário da peste para uma mobilização das perspectivas de Agamben e Esposito, nosso objetivo não é engessar cada um dos autores em determinado sonho. Porém, podemos achar algumas aproximações. Se para Agamben o momento da peste pode significar um desenvolvimento dos dispositivos de controle e de segurança, em uma exacerbação biopolítica que gere um estado de exceção permanente, pode-se dizer que aí estaria caracterizado o sonho político da peste. O policiamento mais vilanesco viria à tona, o controle mais disciplinar estaria posto, e como Paul Preciado (2020) nos lembra em seu texto Aprendiendo del virus, o que o vírus faz é deslocar a instância de ação da unidade de soberania nacional para o corpo individual. Os limites da soberania nacional não são mais as fronteiras, mas sim, nossa pele e a porta de nossas casas.

Já nas intervenções de Esposito, pode-se perceber um outro caminho de reflexão que seria caracterizado pelo sonho literário da peste. Ao refletirmos sobre o insuperável paradoxo que une comunidade e imunidade, podemos pensar: qual outra vida gostaríamos de construir, alterando radicalmente a constituição de nossa comunidade e, consequentemente, instaurando novos padrões imunitários para manutenção da vida em conjunto? Toda a problemática da comunidade e imunidade, definida em termos de população, passa a ser uma problemática que concerne entre sujeitos específicos e os limites de seus próprios corpos individuais. "O vírus atua à nossa imagem e semelhança, apenas reproduz e estende a toda a população as formas dominantes de manejo biopolítico e necropolítico que já estavam trabalhando no território nacional.” 
(PRECIADO, 2020). Assim, a imunidade corpórea não habita apenas o espaço de critérios biológicos, mas também, é construída de forma coletiva a partir de formas de conduta sociais e políticas que são produtoras de relações de poder, gerando processos de "soberania ou exclusão, proteção ou estigma, vida ou morte". É nesse sentido que Preciado (2020) faz a seguinte afirmação: me diga a forma que sua comunidade constrói sua soberania política e eu te direi quais são as formas de epidemia que essa específica comunidade poderá enfrentar e, caso enfrente, também lhe direi quais serão as formas de manejo e controle do vírus.

\section{Considerações finais}

Foucault faleceu em 25 de junho de 1984 em Paris, 36 anos antes da pandemia do coronavírus ser um problema para nossa sociedade. Porém, isso não nos impossibilita de imaginar, caso estivesse vivo, o que ele poderia nos falar sobre tal acontecimento. Toda sua obra, desde a comumente denominada "fase arqueológica" até a última fase, aquela que chamam de "Foucault ético" ou "fase das problematizações", tem um ponto em comum e de importância nevrálgica, que segundo Christian Laval (2019, p. 123), é "o desejo de viver de outro modo e pensar de outro modo". Ao preocupar-se com o processo de constituição dos sujeitos e com os dispositivos de saber e de poder, Foucault está se preocupando com a prática da liberdade e com as maneiras que os sujeitos poderiam experimentar sua vida.

Foucault está preocupado em escrever uma história das experiências -entende-se experiência aqui como descrito em Modificações em O Uso dos prazeres (2020, p. 8), a saber, campos de saber, tipos de normatividades e práticas de subjetivação - nas quais o indivíduo inventou-se, destruiu-se e reinventou-se novamente. Assim, nos parece que fazer um uso da biopolítica e das intervenções de Agamben e Esposito para almejar novas possibilidades de crítica e de resistência aos colaterais pandêmicos, está perfeitamente localizado na trilha do desejo foucaultiano de formular vidas outras nas mais plurais estéticas da existência possíveis. Em um de seus textos jornalísticos sobre a Revolução Iraniana, Foucault nos diz assim:

Há mais ideias na terra do que os intelectuais imaginam. E essas ideias são mais ativas, mais fortes, mais resistentes, mais apaixonadas do que os "políticos" pensam. Cabe assistir ao nascimento das ideias e à explosão de sua força: não nos livros que as enunciam, mas nos acontecimentos em que sua força se manifesta, nas lutas que se travam em torno das ideias, pró ou contra elas. Não são as ideias que conduzem o mundo: mas é porque o mundo tem ideias e porque as produz continuamente, que ele não é conduzido passivamente pelos que o dirigem ou pelos que gostariam de the ensinar o que se deve pensar de uma vez por todas. Tal é o sentido que gostaríamos de dar a essas "reportagens", em que a análise do que se pensa estará ligada àquela do que acontece. Os intelectuais trabalharão com jornalistas no cruzamento das ideias e dos fatos (FOUCAULT, 2012, p. 124-125).

Agamben e Esposito produzem essas ideias a partir das explosões que ocorrem na situação pandêmica. Porém, suas palavras estão longe de ter força de lei. Como poderíamos afirmar que já não existe possibilidade de resistência frente à vida nua, ou de que um novo paradigma imunitário - mais sustentável e interplanetário, como propõe Preciado (2020) - seria possível após os efeitos da pandemia? Tais respostas não existem fora da possibilidade de exercícios de liberdade que almejam a constituição de novas formas de vida.

A vida não pode ser pensada como a única potência afirmativa contra formas de poder. Uma biopolítica positiva ou democrática - como propõe Panagiotis Sotiris (2020) - não pode ser pensada contra algo que seria um biopoder mal, de caráter negativo e destruidor. Segundo Laval (2019), essas oposições seriam muito estranhas a Foucault. Ainda parafraseando Laval (2019, p. 123), "Se queremos viver de outra maneira, 
se desejamos mudar de regime de vida, é preciso se expor ao risco da morte". Não há nada que possa se opor ao quadro normativo do poder, do que uma vontade e uma possibilidade de vivermos e pensarmos de outro modo.

É dessa forma que Agamben e Esposito, ferramentados a partir de uma leitura foucaultiana, podem nos ajudar nesse momento pandêmico: uma possibilidade crítica às definições que nossa vida vai tomando; uma possibilidade de caminhos para construção de novas formas de vida, mais saudáveis e igualitárias. Restanos agora as consequências dessa revolução viral que nossa sociedade assiste.

\section{Referências}

AGAMBEN, G. (1995). Homo Sacer: o poder soberano e a vida nua. Tradução: Henrique Burgo. Belo Horizonte: Editora UFMG, 2012.

AGAMBEN, G. (2014). O uso dos corpos. Tradução: Selvino J. Assman. São Paulo: Boitempo, 2017. AGAMBEN, G. (2020a) “L'invenzione di un'epidemia”. Quodlibet. Acessado em 26/02/2020 e encontrado em https://www.quodlibet.it/giorgio-agamben-l-invenzione-di-un-epidemia.

AGAMBEN, G. (2020b). "Sulla tecnica e l'arte". Laboratorio Archeologia Filosofica. Acessado em 24/03/2020 e encontrado em https://www.archeologiafilosofica.it/sulla-tecnica-e-larte/?fbclid= IwAR2oVleKJLX3_tdOD7VVbol31BfdzyTT5qd2SliQfCt60p16tvkxliNBBj4.

AMADEO, Pablo (Org.) (2020). Sopa de Wuhan: pensamiento contemporáneo en tiempos de pandemias Acessado em 25/04/2020 e encontrado em http://repositorio.uasb.edu.bo:8080/ bitstream/54000/1111/1/covid-rev.pdf.

AVELINO, Nildo. (2012) “Subjetividade e confissão no curso ‘Do governo dos vivos'”. In: GALLO, S.; GUARIENTI, L. B. O.; NOVAES; M. Conexões: Deleuze e Política e Resistências. Petrópolis: DP at Alli, 2013.

CASTRO, Edgardo. (2013) Introdução a Foucault. Tradução: Beatriz de Almeida Magalhães. Belo Horizonte: Autêntica, 2015.

FOUCAULT, M. (1990) “Qu'e est-ce que la critique?" Bulletin de la Société Française de Philosophie, 84/2, 35-63.

FOUCAULT, Michel. (1994) Dits et écrits. 1954-1988. Édition de Daniel Defert, François Ewald e Jacques Lagrange. Paris: Gallimard, 4 v.

FOUCAULT, Michel. (1992) "O sujeito e o poder". In: DREYFUS, H.; RABINOW, P. Michel Foucault: uma trajetória filosófica. Rio de Janeiro: Forense Universitária, 1995, p. 233-249.

FOUCAULT, Michel. (1987) Vigiar e punir: nascimento da prisão. Petrópolis: Vozes, 1999.

FOUCAULT, M. (2003) Diálogo sobre o Poder. In: FOUCAULT, Michel. Ditos e escritos IV: estratégia, poder-saber. MOTTA, Manoel Barros da (Org.). Tradução de Vera Lúcia Avellar Ribeiro. Rio de Janeiro: Forense Universitária, 2003. v. 4.

FOUCAULT, Michel. (1997) Em defesa da sociedade: curso dado Collège de France (1975- 1976). São Paulo: Martins Fontes, 2005.

FOUCAULT, Michel. (2006) “Gerir os ilegalismos”. In: POL-DROIT, R. Michel Foucault, entrevistas. São Paulo: Graal, 2006a. p. 41-53.

FOUCAULT, Michel. (2003) O poder psiquiátrico: curso dado no Collège de France (1972-1973). 
São Paulo: Martins Fontes, 2006b.

FOUCAULT, Michel. (2004) Nascimento da biopolítica: curso dado no Collège de France (19781979). São Paulo: Martins Fontes, 2008a.

FOUCAULT, Michel. (2004) Segurança, território, população: curso dado Collège de France (19771978). São Paulo: Martins Fontes, 2008b.

FOUCAULT, Michel. (1987) História da sexualidade l: A vontade de saber. Rio de Janeiro: Edições Graal, 2010a.

FOUCAULT, Michel. (2001) Os anormais: curso no Collège de France (1974-1975). São Paulo: WMF Martins Fontes, 2010b.

FOUCAULT, M. (2004) Reportagens de ideias. In: FOUCAULT, Michel. Ditos e escritos VIII: segurança, penalidade, prisão. MOTTA, Manoel Barros da (Org). Tradução de Vera Lúcia Avellar Ribeiro. Rio de Janeiro: Forense Universitária, 2012. v. 8.

FOUCAULT, Michel. (2013) A sociedade punitiva: curso no Collège de France (1972-1973). São Paulo: WMF Martins Fontes, 2015.

FOUCAULT, Michel. (2014) Microfísica do poder. 5 ed. Rio de Janeiro: Paz e Terra, 2017.

FOUCAULT, Michel. (2018) Histoire de la sexualité 4. Les aveux de la chair. Paris: Gallimard, 2018. FOUCAULT, Michel. (2014) História da sexualidade II: O uso dos prazeres. Rio de Janeiro: Paz e Terra, 2020.

ESPOSITO, R. (2004). Bios: biopolítica e filosofia. Tradução: M. Freitas da Costa. Lisboa: Edições 70, 2010.

ESPOSITO, R. (2020). “Curati a oltranza”. Antinomie. Acessado em 28/02/2020 e encontrado em https://antinomie.it/index.php/2020/02/28/curati-a-oltranza/

LAVAL, C. (2019) “Foucault e a experiência utópica”. In: FOUCAULT, M. O enigma da revolta: entrevistas inéditas sobre a Revolução Iraniana. São Paulo: N-1 Edições, 2019. p. 103-142.

MBEMBE, Achille. (2018) Necropolítica. 3. ed. São Paulo: n-1 edições, 2018.

MILLS, C. (2018) Biopolitics. New York: Routledge. 2018.

NALLI, M. (2012). “A abordagem imunitária de Roberto Esposito: biopolítica e medicalização”. Revista Internacional Interdisciplinar Interthesis, 9/2, 39-50.

PELBART, Paul. (2013) O avesso do niilismo: cartografias do esgotamento. São Paulo: N-1 Edições, p.345, 2013.

PRECIADO, Paul. B (2020). “Aprendiendo del vírus”. El País. Acessado em 28/03/2020 e encontrado em https://elpais.com/elpais/2020/03/27/opinion/1585316952_026489.html

SOTIRIS, Panagiotis (2020). “Against Agamben”: Is a Democratic Biopolitics Possible? Critical Legal Thinking. Acessado em 14/03/2020 e encontrado em https://criticallegalthinking.com/2020/03/ 14/against-agamben-is-a-democratic-biopolitics-possible/

Artigo recebido em: 31 de maio de 2020

Artigo aceito em: 12 de julho de 2020 